\title{
Pioneer Iowa Soil Subjugation
}

By N. TJernagel

A couple of oxen and a breaking plow, ushered in by the early pioneer, was the first civilized threat to the virgin soil of the Iowa prairie. Nature had entrenched its plant-root network in the ground so firmly that it took much power and finely tempered implements to lay open and reverse its rich, growthy upper layer. Nor was it thus fully subdued, but it must needs be otherwise worked and tended to enable seeds to find a lodging place so as to take root and grow.

The breaking plow with its rolling coulter to cut smooth the near side of the furrow was a simple affair, yet had to be skilfully fashioned so as to enable the walking plowman to hold to a nicety its course in the ground. An irregularly plowed furrow was an abomination to the field worker who came after. Rough harrowings of the newly-turned soil tore into it sufficiently to invite the nestling of seeds; and by another year the soil surface was mellower and less truculent of approach both for the so-called stirring plow and harrow. Upon the introduction of the pulverizer or disk, it became easier to subjugate the sod. The one-shovel cultivator, too, came into play when the soil's surface resistance yielded.

\section{Crop Fields and Fences}

The early fields were irregular in pattern on account of more or less of wet and marshy areas, and in consequence clung to the contours of the hills and uplands; and the fences were usually required to turn and twist in deference thereto. The hardwood posts and rails used for this purpose were of lasting quality and represented much labor in the making. The fashioning of rails and posts was winter work, and hard though it was, jolly, light-hearted participants were usually seen engaged in it. In the Story county area the Skunk 
river timber yielded great quantities of excellent material for such purposes. We always fondled the idea that our own virgin timber, growing in the rich soil of this section, produced just about the finest logs seen anywhere in the state. So much for a bit of bragging about nature's benefits, with small credit to the favored recipient.

Wire, to take the place of fence-rails, and tile for water outlet from the low places that hindered larger field areas, waited some years for development, entailing considerable inconvenience as well as crop restrictions. The wire, when it came, was very durable, but the barbs were entirely too far apart for the uses intended. When the tiles appeared, they were too small, laid rather shallow, and branched too far apart for effective drainage. Experience proved the system's inefficacy, and gave broad hints for eventual betterment. Resulting improvement in method was evidenced in widened fields, and after some years crops flourished on the accumulated humus of centuries stored in the slough areas and elsewhere.

\section{Planted and Rotated Acres}

Flax took to the newly turned soil exceptionally well, but was suspected of impoverishing it if continued too long as a crop in the same place, so wheat took its place after the first seeding or so. Wheat would even do quite well itself as an initial crop, if the season was favorable. The corn was planted in subdued ground alongside, or following, that of wheat. Eventually the wheat gave way to other crops, though winter wheat prevailed to some extent. Oats held its own as a crop, besides serving as a yearly go-between among the various fields, to bolster the soil for corn or other crops. Clovers, too, made their appearance to take the place of the excellent prairie hay, and to enhance soil preservation through crop rotation.

Seed pedigrees were unknown to the average pioneer, nor were the seeds used certified as to weed infiltration or other content. Flint corn and calico corn 
had their day and their uses, as did other, later corn without name and record heritage. But corn improvement went on apace, and production has been on the increase. But through intensive yields we have also depleted the soil as to certain elements as well as productivity. Restoration thereof through suitable fertilizer is now generally required. Incident to the change from the somewhat primitive to other, later modes, there came certain threats to growing things to be reckoned with, which, wherever and whatever the origin, including the ultra-modern bug, et al, threatens havoc among our plants beyond any devastations known to us earlier. However, we do produce more to the acre, but the various measures necessary to combat pests and properly husband the soil to insure a crop have decidedly increased. This applies to farm production in general.

\section{Sowing and Tending}

The grains were sown by hand in the early fields. A man of measured tread, steady arm, and well calculating eye, was able to distribute the seeds with surprising evenness. Some never acquired the knack of exercising the three sowing essentials in perfect co-ordination, hence the grain grew thicker in places, less so elsewhere, and gave more chance for weed growths where, as a consequence, the stand developed more thinly. By means of a one-shovel cultivator and drag used during the very first pioneer years, the seeds were committed to Mother Earth sufficiently well to absorb soil content and grow. With loose soil, and rain in the offing, the drag could sometimes be counted on to do the necessary soil stirring and covering alone. The seedbed was no further exercised before harvest, since the vigorous plants with proper moisture soon rose to stifle all competitors be it grasses or weeds. Rarely did any weed have the temerity to push its head above the growing grain, but the mustard when it came rose self-reliantly to hold its crown of yellow flowers rakishly aloft. However, belated harvests saw other growths, 
especially weeds, raise their heads above the grain promisingly enough. However, fall plowings at the right time after harvest decimated their ranks appreciably in view of future mischief.

\section{Then Harvest Tume Came}

It was unwise to begin harvest before the grain was ripe, but owing to concern about wind and weather some took it too early, and the result was that they were rewarded with shrunken grain kernels upon threshing. Lodged grain was considered of little account since grain-growth was more or less impeded as the straws lay prostrate, whether caused by the weather or heavily fertilized soil. Unless the heavenly elements whipped them too severely, healthy grainstalks had a knack of raising their heads undaunted after each beating, and proceeded to fill out their kernels as compactly as ever.

It was just before harvest that the golden grain looked its loveliest and contrasted so beautifully with the different shades of green roundabout. The endless domain where flourished the billowing grain, the rustling corn and teeming meadow, offered a richer, vaster promise for the future than any known in the annals of man, and no wonder that the first comers who saw its beginnings might dream of its eventual fruition in the form of the breadbasket of the world.

The Cradle

The first method of harvesting grain was by means of a hand-manipulated implement called a "cradle." Wooden fingers fastened to the handle and parallel with the scythe-blade caught the grain as it fell to the stroke of the implement, being deposited on the ground at the limit of the swing thereof. It took a man of considerable strength and practice to do a good day's work and to leave the sheaves in such position that they could be readily gathered up and tied. To get the proper swing to the scythe be it in grass or grain is a precise accomplishment not acquired in a day. It isn't only an exercise of muscle, but that of the mind 
as well. One may wield such an implement with terrific ardor, cut and slash with might and main, yet, without proper skill, there will be only an irregular ragged swath to show for it. Patience in learning the art of swinging the scythe effectively has saved much aggravation and many a drop of sweat in the lives of men.

\section{The Reapers NeXT}

The early McCormick reaper had a sweep so affixed as to revolve vertically from the platform off which it cleared the sickled grain. As the cumbrous thing raised its head in its deliberate upward swing, one would catch his breath in anticipation of impending breakage and disaster. Though clumsy, it hung on and really worked. The rival Manny reaper had its sweep arranged so as to make its rounds horizontally and seemed less awkward than the other. It had a forked head resembling somewhat that of a serpent and when, at the pressure of the operator's foot, it darted forward to clear the platform, it hugged the potential bundle so closely as if loth to discharge it. As it stopped a moment on its next round to regard its prey for another dive the children looking on were uneasy lest it be a sinister threat to them. The Marsh harvester, a later innovation, was equipped with an upper shelf to receive the elevated sheaves from the sickle platform, and here the accumulations were pounced upon by two men standing side by side to tie alternate bundles and fling them deftly aside. The imposing, brightly-painted machine with its canopy top, and its crew of rather gaudy-looking young men operating it, constituted a well-ordered and picturesque outfit that then seemed might well be accepted as the last work in the business of grain harvesting.

\section{Strenuous Harvesting}

The very first reapers were not equipped with selfrakes and a man was stationed at the rear of the platform armed with a long-handled, three-tined fork, and as the grain fell before the sickle and onto the plat- 
form it was his job to work it off in amounts suitable for bundles. One of our neighbors related that he once worked for a man.who had a habit of teasing his helpers. When in reaping he came to a place where the grain stood exceptionally thick he urged his horses on at top speed, ostensibly to gather momentum so as to push safely through, but in reality to test the skill and endurance of his workmen. Our friend plying the fork was hard put to it to keep the platform clear, but he kept on with dogged perseverance, and succeeded, though the effort threatened to disrupt his very vitals.

At another place our friend worked for a hustler who spared neither himself nor his workmen. When reaping grain he drove his horses with fierce energy and vigor. To keep up tying the grain in bundles as fast as the reaper spat it forth was too much for one man, but when it was all down the boss himself took a hand. He rushed in as if to do it all in one sweep, but our friend said to himself, "wait!" The aggressive one worked at top speed to spur the other on, but all the latter exerted himself to do was to hold as evenly as possible the pace set by the former. After two or three rounds about the fields the greedy hustler realized that he had inaugurated a speed-rate that he himself was unable to hold. Our man held it however, and enjoyed seeing the desperate but futile efforts of the other to avoid falling behind. When the dinner bell rang, the taskmaster dropped his bundle like a hot iron, being utterly spent; and on reaching the threshold of his home suddenly collapsed, falling face forward to the ground.

A little later our man was sent to help his ambitious employer's brother, who had a large field of grain recently cut, but unbound. He found the owner's three strapping sons on hand preparing to finish the work, and with his assistance they set to work at a furious rate. But to continue in the cyclonic fashion seemed impossible and, sure enough, a noticeable slackening ensued among the speeders, and before long our Viking found himself considerably in the lead. Later on, the 
hurry-up trio inclined more and more to inaction, while their helper was supposed to, and did, keep the gait till evening.

\section{A Harvest Scare}

Another beginning in our American harvest fields met with some experiences that were both hard and disagreeable. It was the custom in the early days that four workers tie the bundles after the reaper in the same number of equally long sections about the field. Each worker continued the section next to his own, thus alternating from section to section. If the men were somewhat equal as to speed, and the driver did not force his team, the balance held, and the harvesting went like clock-work. In the instance of which we relate, there was a rift in the proceedings in that one of the workers was able to bring up a little quicker than the others, and could take little rests in between. Somehow this action did not make for amity between the workers. Especially did it irritate our beginner, who had to work in desperation to keep up, and had his heart hopping into his throat for his pains.

Meanwhile the reaper hummed its relentless note, and there were other troubles, demons we should say, lurking nigh. The grain that year had lodged considerably, making it slow work to sort out enough straight straws for a band to tie each bundle. In one place, as he was working with some unusually crinkly stuff, something cold slid over his hand, but being sorely pressed for time he could not stop to investigate. As he started to form the next bundle something on the chilly order slid around his left ankle, and upon looking down-oh, horror!. The tail of what he took to be a rattler showed beneath his trousers. He claimed that he made about forty frenzied hops in the next few seconds, for he was bent on ridding himself of that viper quickly; and he did. He. was less particular about sorting the straws after this, and he even threshed out some grain by vigorously slapping the potential bundle 
to scare away other possible lurkers that might be lying underneath in ambush.

\section{Grain Shocking}

If the bundles were properly tied, it was a pleasure to pick one up with each hand and set them down side by side with a thud to enable them to stand firmly on their own feet. If they were let down lightly and flung carelessly together without mutual bracing, they were almost certain to sag this way or that and invite moisture to permeate the shock. Round shocks with a bundle placed fanwise on top the better to preserve the heads of grain were often made and were effective, as long as the wind didn't lift their hats off, thus leaving the somewhat flattened top open to the elements.

In the so-called long shocks eight bundles were placed in successive pairs in a north and south direction, so that either side gained its fair share of the day's sun thus dispelling dampness. It was not unusual to see an inexperienced worker pursue his task without particular reference to the compass, as also to drag the bundles together pell-mell without proper regard for individual footing or common bracing. In a week there would be a formless heap drawing moisture in place of an up-standing shock drying out. The unsympathetic way some shockers handled the material made one wonder if their action came from a state of mind, and might be applied to their touch of living, breathing things as well.

\section{BundLe LoAding}

To load bundles on the grain-rack for stacking, to the uninitiated might seem easy of accomplishment, yet has its share of difficulties. Since the work must needs proceed apace there was not much chance on the instant to arrange to a nicety of bundles hurtled from below into position on the load, so as to keep the proper equilibrium. The butts of the grain face out, so not to slide downwards too much; otherwise separate bundles might slide out, especially if not held down uniformly by upper tiers. Nor might the heads 
of the grain be placed so as to sag inwards, hindering the maintenance of proper consistency in the center, else the load would taper off too quickly and be pyramided out of proportion. The latter form of loading was usually perpetrated by greenhorns, resulting in light, tall loads and a precarious teetering on top by the unskillful builder as he took his creation to the stacking place. Sometimes, the same performer would fix his stuff so shakily that the load would disgorge as much as whole shocks from its sides or hind portion, and thus necessitate much replacement work. And again, the builder's balance, or lack of it, would induce him to pile on bundles in a manner to emulate the leaning tower of Pisa; and, on the way to the unloading place, down he and his load would slither all asprawl without postponing the possible collapse.

Often the younger helpers would be left. in the load as levelers-off for the pitchers; for sometimes the bundles would fly aloft so rapidly that the poor fellow above was on the point of being covered, even smothered, not to speak of being able to divert the bombardment into any appreciable semblance of order. Owing to this situation the pitchers frequently preferred fashioning their own loads from their position by the grain shocks, thus avoiding any awkward manipulation by either pitcher or loader.

\section{Grain Stacking}

Having thus deftly formed the load in a manner to his own satisfaction, the pitcher was later enabled to fork the regularly laid bundles steadily, as well as precisely, to the stacker, and he to lay them properly in place quickly and efficiently. Any pitcher who flung his bundles at random, either through natural awkwardness or sheer carelessness, exhausting though the work might be,' courted the dislike of the stacker. The stacker of yore moved about on his knees rightly to accomplish his work, and his very pose and position called for skill and attentive concern on the part of the pitcher. 
One of our near neighbors built grain-stacks that were a perfect example of the skilled stacker's finished art. They stood perfectly balanced, were symmetrical in outline and beautiful in design. Utility was combined with form, the bundles being laid so as to pack more closely in the center, allowing thus the outer parts the more readily to settle, which, together with a uniform tapering toward the top, rendered the stacks waterproof. Another neighbor with an eye for design, but who was unpractical in method, overlooked the fact that a stack must be kept exceptionally firm in the center, and built stacks that looked like clean-cut cameos at a distance but, lacking inner stability and firmness, drew water upon settling.

It happened once that a "new beginner" endeavored to build a grain-stack on our farm; but his manner of construction was faulty. There was not enough cohesion among the bundles laid to form a compact, solid mass, and they slid and separated, so that the monument of sheaves he was rearing settled disproportionately as the work progressed. But our man kept to his principle, or lack of it, and added tier upon tier, up and up, on the quivering substructure till he stood so high that no fork was long enough to toss aloft further material. Most of the field having been thus loosely conglomerated in one enormous stack collapse was inevitable; and it came, and the mammoth pile fell apart, slipped and slithered for rods, while the devoted architect disappeared in the ruins.

One of the helpers who had been standing by and viewing with bewilderment the crazy structure, noted the first signs of its disintegration, but was barely able to save himself from the avalanche of bundles that came tumbling toward him, threatening to overwhelm him. When he saw the sorry-looking stack-maker emerge from the tangled wreckage, the ludicrous picture touched off his funny-bone and made him weak with laughter, which merriment, truth to tell, was not greatly appreciated by the unlucky stackbuilder. To 
reconstruct the ruin took longer than had the original mis-construction, and when finally completed, four stacks, instead of one, reared their silhouettes against the horizon.

\section{WORKER'S LUNCHEON HOUR}

The daily luncheon hour, especially during the graingathering season, was much enjoyed by the workers. Well before it was due mid-afternoon, eager glances were directed homewards to catch first possible glimpses of bobbing heads of the child contingent delegated to bear forth the precious refreshments. Sometimes a dog or two, even the cat, joined the procession field-ward. The dogs had an eye for possible crumbs that might fall to them, and looked their desire most eloquently as their masters munched coveted morsels.

Once a small helper, always anxious to serve, was sent abroad quite alone to deliver the luncheon. When, at last, he arrived and saw his pappy only a few steps away he started to lope and down came the cookies, coffee and all. He picked himself up and returned bravely for a fresh portion. When he reached daddy this time he looked up, and not down, thus failing to avoid the lump that felled him just before handing over his little coffee offering. He was now all sweat and tears, but we may be sure he persevered, went on to victory, and not defeat. Another valiant hopeful set out one day in full luncheon regalia, hands and arms employed when, of a sudden, it occurred to him that one of his ears itched. He stopped short and sang out: "Elizabeth, come scratch my ear!" which request having been duly complied with, he left snugly fixed to carry his tasty offering to the expectant ones in the field.

Incidental to the luncheon hour we are reminded of an attempted runaway by the team of a hay hauler who was enjoying his coffee at the moment. Insensibly the driver held on to the drinking vessel with one hand while tugging at the lines with the other and lo! succeeded in holding the horses in check, yet without 
spilling his precious beverage. Many a yarn was spun during the luncheon respite and helped give delightful pause in the midst of the day's drive, be it work or worry.

\section{Early Threshing Modes}

The earliest comers used flails to separate the grain from the husk; later oxen were set to tramp it out. After horses became more general, these did the tramping. Grain separated thus, when intended for milling purposes, was not only fanned, but also washed. This threshing method was eventually superseded by treadmills in which cows and oxen supplied motive power to a cylinder bristling with wooden pins. These trusty pins were made to revolve so fast that the grain was knocked out in a hurry; but when steel cylinders took their place the kernels just flew and the most stubborn heads of grain had to yield their full content. It was an improvement on former methods, but when the first regular threshing machine appeared, though minus stacker and scores of later improvements, the pioneers gazed in admiration at its efficient performance and soon adopted the new way in preference to the old. Those days the grain was uniformly stacked and cured before separating, shock threshing being practically unknown. The rather crude, horse-powered machines did not perform with much dispatch, hence the lengthy threshing runs resulting therefrom would sometimes be extended into mid-winter.

\section{W.ATCHFUL YOUNGSTERS}

The youngsters of long ago were not used to novelty in its present-day amplified form, and experienced exquisite thrills merely at the sight of a threshing-machine as seen from a hill-top, or as it drew into the yard for the yearly threshing. The placing of the horse-power, the driving of stakes, the insertion of the levers and tumbling-rod accompanied by the rattling of chains and pulleys, and neighing of horses-all this, together with yells and commands and eager talk, served as an exciting introduction to the work proper. 
There was a machine-tender, and a feeder and a driver, and these august personages were looked upon with a regard akin to awe by the young pioneer boys. What if they, too, should some day come to occupy exalted positions such as they now upheld before them personified in the very flesh! To hear the gurgle of the cogs as the driver lashed magnificently about him with his whip to start several spans of horses, together with the groaning of the separator as it responded in a gradual acceleration of speed, was fearfully fascinating music to the listening urchins who had edged as near the dangerpoint as possible so as to lose no detail of the enthralling spectacle.

\section{Bundle Pitchers}

There was usually a terrific scramble among the pitchers to get favored positions among the stacks so as to have the wind in their favor both in helping boost the bundles on their way, and to avoid the flying chaff and dust. It was good-natured rivalry, however, and the first to gain a favored stack-top held to his place without interference. A long-legged jackanapes and natural-born clown-long live his memory-would mount the stacks in about three inelegant strides, hop from one stack to another, and crow in frolicsome glee in emulation of the cock-a-loo-loo of the victorious feathered champion in the barnyard. He kept his fellow workers in constant good humor through his gay antics, performing his share of the work meanwhile as though it were a mere side-issue.

\section{The Strawstack BuILder}

Now as to the poor wretch sunk in travail in the strawstack, all readily admitted that he had the hardest place; nevertheless, the very meanness of the unenviable position caused him to be the popular butt of many jokes and jibes. The threshing outfit would preferably be placed so as to have the wind in its favor, thus giving the architect of the strawstack the full benefit of the flying chaff and dust. Even when well-nigh overcome by his exhausting task there would 
be no seeming sympathy, but there might be mirth, by being its focus. His only consolation was that the next strawstack would claim another victim and he might have revenge by being as merciless as the rest. However, underneath the joshing and seeming indifference, there was no ill will, and no one would hesitate to jump to the aid of anyone in actual need of assistance.

\section{Grain Measuring}

The grain was measured by the half-bushel, and as the early machines threshed much more slowly than do modern separators, the caretaker could mark and empty the measuring-casks with comparative ease. Convenient sacks at hand were filled by the output and transferred by the men to waiting vehicles or direct to the grain bin itself.

\section{The Band Cutter}

The band-cutter, who stood beside the threshing machine's bundle platform, was provided with a sawtoothed knife blade, with which to sever the strawbands around the bundles delivered by the pitcher. Strawbands were later displaced by binder twine. It was necessary to cut deftly and surely, so as to sever the band at the first stroke in deference to the exploring fingers of the separator-feeder who was constantly reaching for fresh material. When it happened that unskillful pitchers would fling the bundles criss-cross on the platform the bandcutter was at his wits' end to do his work properly and at the same time avoid gashing the hands of the feeder. However, accidents would happen, and then there was generally a great to-do to determine on whom to place the blame-as if this helped remedy matters. Once in the course of a busy day's threshing, a nervous new-comer threw a bundle that had become entangled in his teaming reins directly into the separator, which soon drew the reins taut, causing his team to back and rear. With ready presence of mind the feeder grabbed the band-cutter's knife, severed the lines and flung the remnants at the head of the gaping driver. 


\section{The Separator Feeder}

To be a successful feeder, well-planned action was found to be necessary in spreading and adjusting the sheaves properly before their introduction into the maw of the separator, so as to hinder glutting as well as to hold the machine to its proper motion. When given too heavy a dose the overcharged cylinders slowed perceptibly, a prompt easing up in feeding being required for their to resume their wonted hum. Close attention was essential, for the whirling iron men would spare no fingers or hands that ventured too near shoving in the grain. There were instances of incautious workers losing hands and arms in this manner; and even worse calamities were not unknown from such cause. A thresherman from Ames, while tending the machine, accidentally slipped into the separator opening and the cruel cylinder teeth promptly nipped off one of his legs, causing it to be severed near the thigh.

\section{Threshing Dangers}

The tumbling-rod, too, held a menace. We have in mind a young man of Roland, Iowa, who while tending his machine came in contact with the revolving rod powering the same, with the result that it took a twisthold of his clothing and before its motion could be stopped had stripped him completely. Because of his durable, heavy clothes he was badly bruised as the high-powered rod wrapped itself in the fabric and ripped it from his body. Though he was threatened with strangulation and turned black and blue in spots, he emerged whole with the benefit of a scare and a lively sense of his own carelessness for future reminder.

There was always potential danger for those in charge of the horsepower, such for instance, of being accidentally caught in exposed cogs, falling off the levers while entering upon the driver's platform, or in getting tangled up with unmanageable horses. On one occasion a crash of thunder started a stampede among the teams and 'round and 'round they went at high 
speed until the machinery parted, whereupon the frenzied animals jerked loose and scattered in every direction. Most of them entered a narrow lane where a girl had fallen unconscious from the effect of the preceding lightning-bolt. Though the horses ran wildly they instinctively lifted their feet away from the prostrate form in their path, leaving her unhurt.

\section{A Threshing Misfortune}

Machine-breakages, and long and unavoidablè delays due to wind and weather, happened then as now. And there were other setbacks. The work in the instance of which we here relate began all but auspiciously. The boss thresherman, who was tall and well proportioned and an ever gallant ladies' man in making obeisance to the pretty inmates at the home on the farm where they threshed, nearly cracked his skull upon accidentally bumping his head against the upper casement of the low outer door of the log-house. However, we surmise that he had his consolation when deft feminine hands administered balm to his aching temples, soothing him in his temporary downfall. To him it was perhaps not so distasteful to tarry, but when through untoward circumstances, it took days and days to complete the threshing job and practically the whole carcass of a newly butchered cow to feed the crew, the owner's hoped-for gain was reduced considerably. But at the next delay came the other fellow's turn to offer up his cow or pig, the law of averages decreeing that in the end no one is individually left with all the bad luck. Neither does good luck choose its favorites in the same place as defeatism so often will have it.

\section{A Thresherman of Parts}

Years ago there lived on the then sparsely settled prairies a so-called easterner; who was a politician by choice, but a farmer and thresherman by profession. When engaged in threshing some of his sons usually accompanied him to lend a helping hand in the work. $\mathrm{He}$ also had with him 'a drove of gaunt, ill-assorted horses. These gained sustenance among his good-na- 
tured customers and fleshed up considerably during their long vagabondage throughout the countryside while the threshing season lasted. He hitched three of his nondescript nags abreast on separate power levers, where a good two-horse team such as supplied by the neighbors, sufficed. They humped along as best they might to the tune of the "blacksnake" and much forceful talk from the driver. There was a constant relay from his dilapidated stud of hobblers and so, with the aid of local teams the ill-conditioned beasts and the groaning machine droned into action and, sooner or later (mostly later), the grain was threshed. Our friend was possessed of a sanguine, unworried temperament; and once having begun a political discussion this had to be threshed out to a finish, other threshing notwithstanding. Many thought his political ideas clever, but is it not so that some hit upon brilliant ideas that they, themselves, do not always perpetuate?

\section{Haying Methods and IncDents}

During the pioneer beginnings on the prairie the wild grass was cut with scythes, and when fairly dry was set up in cocks to cure and be ready for stacking. Before mowing machines appeared grain reapers were equipped with adjustable sickles for mowing. Onehorse rakes took the place of hand-rakes and swept the hay-swaths into windrows. Thereupon, the rakes bunched the hay in suitable bulk for cocks by straddling the windrows. Sometimes the bunched hay was hauled direct to the stack without further ado. The bunched hay when set up in cocks on the meadow, and later built into well-made haystacks for final curing, made far more palatable and nutritious feed than does the too common, hurry-up custom that the hay be yanked from the swath or windrow into the hay-mow prematurely in view of a quick finish. Often as not it is either too dry and crinkly, or too damp, to retain the greater nutritiveness and flavor.

In the early days, the hay-racks were usually without frames, the loads being built up on the flat rack- 
platform in a manner to sustain themselves without lateral support. As the loads were usually formed wide and large, it took considerable skill to place and find properly the deluge of forkfuls flung aloft by rapid pitchers to the panting toiler doing the loading. To move around in the yielding mass, and to guard against being toppled over by a sudden forward movement of the team, was difficult enough in itself without the menace of being smothered by the merciless bombardment from below.

When the mercury climbed high and the sun's direct rays were added to the warm, springy trough the loader must perforce stamp around in, the work became well-nigh unendurable. The heat in the load being greater than in the surrounding atmosphere because of the loader's placement and the hot hay-fumes, especially during calm days, one risked sun stroke by too strenuous exertion. This applied particularly during work in dead air pockets near groves or in ground depressions. The pitchers, too, had need of exercising caution. Death nearly claimed one of our men who was overcome by heat while loading under such conditions.

Other difficulties there were, such as loading hay from grass with rather smooth stems, for it tended to slip easily and made the uneasy load-builder feel as if he were standing on a bed of pin-feathers mixed with quicksilver. Once our man in the load had to slip off the rack from under him, drawing his fork with it, and when he, too, followed suit and slid along, he met the fork with tines upturned, which caught him in the leg. The wound pained him greatly for many days, but since it was by the merest chance that the tines did not penetrate his abdomen, he nursed his lesser hurt with thankfulness.

Two of our neighbors, both being given to pleasantries while at work, were hauling hay. The witticisms of one touched off mirth in the other. The wag was loading and boasted that he could build as large and 
shapely a load as anybody, and encouraged the other to shove the forkfuls along, the faster the better. He outdid himself, so as to show his friends what he could do, daringly increased the length and breadth of the load, and self-confidently proclaimed that nobody had anything on him when it came to building a No. 1 load of hay. Though racked with mirth at the jolly braggart's capers the devoted pitcher expressed himself dubiously concerning the other's handiwork, continuing, however, to deliver forkful after forkful to supply the insatiable demands of the prize-performer above operating so expertly.

By the time the load had taken. on the dimensions of a medium-sized haystack and the builder was challenging anyone on earth to form a better one-swish! down it came with its maker, and no more was said.' Then it was that the pitcher was seized by an uncontrollable fit of laughter that sent him reeling to the ground. As he sank helpless he grew blue in the face and at last lapsed into a coma. The peerless loader, for one, didn't laugh, nor did the stricken one's wife, who was passing by with two pails of water suspended from her "vassal" wooden shoulder rests. She immediately flung some water into the face of the sufferer, which restored him, and after a pause the haying was continued, though in more modest fashion. Few, if any, have died from laughing, but pity on those who have lost heart and strength for want thereof!. Hail to the devotees of wholesome mirth and fun-making! The pioneers set fair example.

\section{Seed Corn Gathering}

In the early days seed corn was left to mature on the stalks, only to be snatched from the field ahead of the killing frosts. Those who selected seed corn from their cribs risked the hazards of frost and unfavorable curing, and might invite poor germination at planting time, with consequent thin stands. After choosing suitable corn-specimens for seed, enough of the husk was left intact so that two ears might be tied and hung 
jointly. These were suspended in rows, pair by pair, in the attic or other drying place. The mice loved to nibble the exposed part of the kernels on the ear, but if not too deeply gnawed the kernels when planted usually germinated and grew. Given access to every nook and corner the cats, though sometimes themselves a nuisance, kept mouse and rat production low and seed preservation fairly well insured. It sometimes happened that those who were careless about their seed corn supply would be obliged in the spring to scour the country for left-overs, only to find himself limited to the offerings of butt-end kernels and discarded earends.

\section{Corn Planting}

The corn was usually planted around the second week in May, or soon thereafter. The seed-bed was worked mellow and smooth, and a horse-drawn marker cross-marked the field so as to form three-foot eightinch squares throughout. In each cross formed by the marker three kernels, preferably, were dropped by hand and hoed over to a depth of two to three inches, according to the soils moisture-content. Nimbly-stepping barefoot boys would usually do the corn-dropping; however, to acquire instant grip on just three kernels and place them quickly just where the marker impressions met, was a ticklish business and also held them painfully alert concerning the merciless hoe dogging them in the rear, manipulated by some brisk grown-up. To a practiced hand one short, backward drag of the hoe, sunk to a proper depth in the ground, was sufficient to cover a hill of corn; and each step of the hoe-handler was timed to pack down the loose earth topping the kernels.

Later came the portable corn-dropper carried by hand and thrust into the ground to release a given number of seeds automatically after each shove. And in a few years came the two-row machine planter drawn by horses and equipped with a dropper manipulated by a man seated sideways on the machine in 
front, enabling him to sight the cross-rows and to aim the seeds thereinto by a well-timed pull of the releaselever. To hit that particular bullseye, the very center of the cross, during a variety of speeds and motions originating with the team or driver, took markmanship of the first order. When the check-rower came, it added another improvement in the form of a wire strung across the field with a knob catching the lever automatically to drop the corn in the hill properly as to direction, which, in turn, enabled the expert at the dropping-lever to relinquish forever his tedious job.

Corn Tending

Soon after planting, the ground was harrowed to discourage the growth of weeds and ready the soil for corn plowing. Drags with wooden pins saw frequent use in the early days. The so-called blind-tending consisted of plowing between the rows of the planted corn before it was up, without harrowing.

Corn-tending was done at first by means of a onehorse, one-shovel cultivator; then came the doubleshovel, as also the full row, two-horse machine, all equipped with handles to operate the shovels by the man walking and manipulating them from behind. The riding cultivator appeared in due time; constant care being required to exert proper pressure on the shovel handles, so as to work the soil rightly for the better growing of the young corn. Three plowings, sometimes four, were formerly considered to be about right, judged according to the soil and season; and the corn in most years would be "laid by" right around the Fourth of July.

It often happened with some farmers that the last plowing, especially, served not as a benefit, but a detriment in that the shovels were not set to the best advantage and came too close to the growing corn, or dug in too deeply, so as to sever some of the life-lines, the surface roots. To this day such damage often is caused at time of favorable corn development for want 
of caution in this respect. A shallow stirring of the top soil best serves its purpose.

The Roasting Ear

After plowing, the corn rustled, wafted abroad its pollen, and otherwise communed with itself until roasting-ear time, usually in August, when it would be invaded by corn epicures in places where the ears ripened suitably for picking from day to day. For the household the corn was mostly cooked and was consumed with rare enjoyment. It was generally eaten off the cob, horse-fashion, both hands being employed in the process of feeding. We need not infer from such manner of eating that it implied slovenliness or lack of good breeding.

Out in the corn-field, under the stars, the youngsters built fires for corn roastings, with inclusion of gaieties that waited long for the end. No youthful stomach seemed ever to lack capacity in the consumption of green corn prepared just right, and with watermelon honestly filched in an adjacent field and consumed with it so that sweet juiciness might course along to aid digestion-yes, that was living! According to James Brown early wolf packs, too, out for a lark of their own in the moonlight and prowling around amongst ripe watermelons, devoured them voraciously.

\section{The Field Gophers}

The corn-field held other attractions than its own particular product, for besides melons there grew vegtables of various kinds. Mostly these were huddled in places where the squirrel or other creature had decimated the stand of corn. The young boys were not squeamish about drowning out these mischievous rodents-as if they enjoyed the ghastly business. The miserable gopher would be drenched and come out of his water-filled hole all bedraggled and gasping for breath, only to meet a death more horrifying than that already threatened, being promptly committed to clubbing or the gaping jaws of Fido. Trapping was no more humane, but shooting was reckoned so. 


\section{Field Vegetables}

Whatever his fate the gopher's activity seemed to have been for the purpose of providing open spots in the field where other things might have a place in the sun besides corn. And so, turnips found a place there and grew so soft and sweet that even young corn and watermelon sometimes awaited preferment. One often tangled 'mongst creeping vines and tumbled over the pumpkin, too, midst the corn rows; however, a taste of its flesh in the raw, cow palates excepted, was not agreeable, but lo! the next day saw its golden content rendered luscious in the form of pie, a ravishing appetite-charmer indeed! As to beets, there was usually sufficient production and to spare, and when cut into they looked most appetizing; but only cooking, with or without vinegar, made them really palatable. Carrots, too, were the more frequently served cooked, yet were toothsome in their native right through Nature's own process in ripening.

There were other garden products, potatoes, cabbage and all; and currants and gooseberries were strung the more permanently beyond the field-side and blossomed and bore profusely and bountifully. And as to the wild strawberry that blushed twixt the grass in the undisturbed meadow near by-its luscious body contained tastiness quite unequaled elsewhere.

The virgin soil had caught and imprisoned the proper combination of elements to produce the acme of agreeable flavor, as also other quality now partly lost through intensive use of the soil; which, is largely the reason for the numerous ingredients advertised to add to our foods and feeds, so as to make them properly nutritious as well as intriguing in quality and, shall we say, expensive.

Garden plots near the homestead came more and more into vogue for a handy vegetable supply, while the gopher-spots in the field, when not checked and used, were taken over by the over-present fox tail and other weeds that had the temerity to push in beside it. 


\section{Corn Husking}

The corn was brought to fruition and drying finish usually during those same romantic fall days when the forest foliage assumes the attractive coloring that so delight the eyes and soul. The outer aspect of the field itself lent charm to the landscape, with its creamy tint as contrasted with the colorful mantle of timber and meadow. Then came frost, also the drying wind, which sent the leaves scurrying and causing, at times, the corn stalk itself to stoop to earth. The husker did not fancy the leaners, being loth to bend his back to glean the corn, ears that had individually taken only a second or two of his time to produce, all other preparation thereof being due to Nature's vigilance, every instant, over a period of ninety days or more. How insignificant the sower, yea, the reaper as well! Again what honor bestowed on man, the weakling, that he may harness all creation to serve him.

\section{Corn Picking Methods}

In the early days the ripened corn was picked into linch-pin wagons drawn by oxen. Horses, too, were used, and eventually the lumbering bovines were crowded out. There were often as many as four persons in a corn-picking outfit, and instead of each husking a hundred bushels or so, as is done by one-man outfits today, sixty bushels a day frequently proved to be the limit of their combined efforts. They drove into the field so as to straddle a row, which row was the job of one man to stoop for, and stay stooped, picking. 'till the end was reached. Two men on either side of the wagon each grabbed a row and did their best to husk so fast that the plodding toiler on the "down row" behind had to hump along with all speed to hold his own. Sometimes one man on each side would suffice to keep the procession moving, especially if a boy helper assisted behind or before wherever he could manage to get in somebody's way. Sometimes a youngster sat perched in the wagon as driver; serving, besides, as a target for mischievous nubbin-throwers, 
being also a harassed forerunner of the future throwing-board. Eventually the husker worked on one side of the wagon only, threw the corn against the throwing-board topping the wagon-box to the right, and steered his team to enter a convenient row of corn already husked, which row was followed to its end. This allowed the misused gatherer in the rear to straighten up and cease throwing forward, advance, and engage in a sideways bombardment of the "bang-board," both to advertise his noise as well as vengefully shattering the ear-ends.

There is no surer way of acquiring a sense of accomplishment than to be able to climb into one's own wellfilled wagon of golden corn, and later to store it for proper safe-keeping in a snug well-built corncrib. Not only the husking, but shoveling out the load, took its toll of muscle, also sweat; but what of the sweet rest and the loyal spread in immediate prospect?. The work of cornhusking is justly celebrated as the greatest known invitation to a healthy appetite; and it discourages dyspepsia and kindred ailments at the expense of pills. The crisp autumn air sends the blood coursing through the worker's body, flexed $\bar{w}$ ith muscular activity throughout the day, which calls for extra-generous rations. Through such exercise of a person's whole system one is introduced to sleep in normal, healthy fashion; but what of the morning after, when the newfangled alarm clock bursts upon the eardrums like a firing squad and forces one as inexorably to stand forth for another day's venture. Yet, after the getting-up agony is over and the dress-up ordeal accomplished, that blessed propensity, the appetite, re-asserts itself and soon breakfast gives zest for another day.

\section{Frosty Picking}

Many a husking day's beginning proved unpromising; a heavy frost in the morning made the work particularly disagreeable because of the clinging moisture lent by the frost. When at sunrise Jack Frost's handiwork glistened so beautifully in myriads of tiny reflections, 
alas! it was impossible for the bedraggled husker to rave about them, but rather to implore the sun to annihilate those tricky crystals, so as to ease their bite on his drenched arms, hands and legs. In an appreciative appraisal of the wonders of nature one must be largely unaware of his members, for a pain or weakness here and there may mar his perceptions, disturb his reflections and dull his appreciation. Thus a glowing, picturesque sunset, with the husker comfortably perched on his load homeward bound, not only could be fully prized by him, but would be delightedly referred to in the family circle later.

\section{Handling Restless Teams}

There was much yelling at the teams by the huskers in the fields, either to correct too much speed, or the lack of it; but sometimes there were drivers who spoke softly, yet exercised the better control. One young man addicted to profanity, which was frowned upon in the home, gave vent to it in the field where, in thunderous tones, he requested the Maker of his decrepit nags to consign them to everlasting perdition. Listeners, not too far removed, might hear his fervent appeal repeated with variations throughout the entire day. Another worker who must needs repress somewhat similar sentiment, with which he burned inwardly during the day, swore blue streaks in his sleep at night. Profanity, however, was more the exception than the rule among the majority of the workers.

Upon the advent of cooler weather in the late fall young work horses, especially, grew frisky in the cornfields with the result that runaways occasionally occurred. Sometimes the take-off would be so sudden and stealthy-like that the husker, busily intent on his work, might throw an ear or two into space before missing the bang-board's answering knock. However, if the momentum gained by the team was not too great he would sprint to reach the endgate, hoist himself into the load, grab the lines and, surprisingly enough, belabor the horses therewith and run them to 
exhaustion back and forth in the field. This was the better cure for a repeat performance, at least for the day. There was danger in a threatened runaway for the driver to try to catch the lines from the side of the wagon since he might easily misjudge himself in the excitement and be dragged under the wheels. This danger also applied when stooping to haul forth ears of corn accidentally thrown under the wagon and in being caught in the act by a sudden lurch of the wheels. The little fellows had a woeful knack of figuring in such accidents.

And it could be painfully unpleasant when two were working together and the outside husker might accidentally let fly a nubbin into the ear of the other, making it sing, and even bleed. If repeated too often the misused one might be tempted to return a similar missile with interest. Gloves were not worn by the cleanhusking pioneer, and the result was sore and bloody fingers that left their tell-tale marks on many a cornstalk. Sometimes huskers would thoughtlessly overdo in the beginning of the husking job and thus develop muscle-strain. Such undue zeal brought them but scant sympathy while they must needs rest and recuperate.

When the corn stood straight and the ground was firm, husking was not a disagreeable task, but when storms laid the stalks flat and rain soaked up the soil, it represented back-breaking work for the men and extremely hard pulling for the horses. Floundering about with feet in the mud that felt like lead was tough; and then to hear the harness snapping just when starting for home did not contribute to serenity of mind. However, to solve his troubles and diffiulties of this kind with skill and dispatch was, and is, the farmer's business, and tends to place him right at the top in resourcefulness. Now the mechanical corn picker bids fair to replace hand picking altogether, as a former era bows itself out. . 
Copyright of Annals of Iowa is the property of State of Iowa, by \& through the State Historical Society of Iowa and its content may not be copied or emailed to multiple sites or posted to a listserv without the copyright holder's express written permission. However, users may print, download, or email articles for individual use. 